Canadian Journal of Higher Education Revue canadienne d'enseignement supérieur

Volume 45, No. 4, 2015, pages $101-122$

\title{
Internationalization in Canadian Higher Education: A Case Study of the Gap between Official Discourses and On-the- Ground Realities
}

\author{
Marianne A. Larsen \\ University of Western Ontario
}

\begin{abstract}
This case study about one university's internationalization initiative, known as North Goes South, provides a nuanced and finely grained understanding of what internationalization looks like in practice. The study was guided by a desire to probe the perceived impact of a Canadian-East African internationalization initiative on students, faculty, and Tanzanian community members. The article begins with a brief review of the literature on internationalization and higher education in Canada. The rationale for using a case-study methodology is presented, along with the background and context of the case. Following an outline of the research methods, the study results are reviewed to show the complex and contradictory ways in which this internationalization initiative played out in one higher education setting, pointing to the gap between official discourses of internationalization and on-the-ground realities.
\end{abstract}

\section{Résumé}

Connue sous l'appellation « North Goes South » (Le Nord va au Sud), cette étude de cas concernant l'initiative d'internationalisation d'une université en particulier fournit une compréhension nuancée et finement détaillée de ce à quoi ressemble l'internationalisation dans la pratique. L'étude a été guidée 
par un désir de sonder l'effet perçu d'une initiative d'internationalisation canadienne-est-africaine sur les étudiants, le corps professoral et les membres de la communauté tanzanienne. L'article débute par une brève recension des écrits sur l'internationalisation et l'enseignement supérieur au Canada. Nous y justifions l'utilisation d'une méthodologie d'étude de cas et y présentons le fond et le contexte du cas en question. Nous dessinons ensuite les méthodes de recherche et examinons les résultats de l'étude afin de révéler les manières complexes et contradictoires de concrétisation de cette initiative d'internationalisation dans un cadre d'enseignement supérieur, soulignant ainsi l'écart existant entre les discours officiels d'internationalisation et les réalités sur le terrain.

\section{Introduction}

Internationalization is a key feature of higher education in the early $21^{\text {st }}$ century, and Canadian universities are no exception to this global trend. Over the past 15 years or so, international initiatives related to student and faculty mobility, international research partnerships, and the internationalization of curricula have been taken up across Canadian postsecondary institutions. Indeed, the majority of Canadian universities and colleges view internationalization as a high priority; as a result, they now include internationalization as a key goal in their institutional strategic plans and internationalization among their top five priorities (AUCC, 2014).

Jane Knight, whose definition of internationalization is most quoted in the related literature, notes that internationalization occurs at both the institutional and the national/ sector level, and that while the national/sector level has had an important influence on the international dimension of postsecondary education, "it is usually at the individual, institutional level that the real processes of internationalization is [sic] taking place" (Knight, 2004, pp. 6-7). Knight's proposition is to use both a bottom-up (institutional) approach and a top-down (national/sector) approach to understand the dynamic relationship between what is happening at the two levels. In this article, I focus primarily on the bottom-up approach in order to provide a more nuanced and finely grained understanding of what internationalization actually looks like in practice. Specifically, this is a case study about Johnstone University's initiative to internationalize, known as North Goes South (NGS) ${ }^{1}$, a north-south partnership that includes international research collaboration, student and faculty mobility, and international service learning (ISL).

The problem that I set out to understand was how Canadian university students, faculty members, and Tanzanian community members involved in NGS view the impact of the initiative. The study draws on qualitative methodology, given my interest in the research participants' perceptions of their roles in the initiative and their understandings of the overall benefits and challenges of NGS. I begin with a brief review of the literature on internationalization and higher education in Canada, with a focus on the literature most relevant to my study. I provide my rationale for using a case-study methodology to understand internationalization, and the background and context of the case I am studying. I then review the results of my study to show the complex and contradictory ways that internationalization was played out in one higher education setting, pointing to the gap between official internationalization discourses and on-the-ground realities. 


\section{Literature Review}

As internationalization has become an increasingly significant policy in Canadian higher education institutions (HEIs), scholarly literature in the field has emerged, albeit slowly. Most authors have focused on specific approaches or strategies commonly associated with internationalization in Canadian higher education. A review of publications over the past five years reveals an emphasis on the following themes: internationalization of the curriculum (e.g., Beck, 2009; Garson, 2013; Hanson 2010; Odgers \& Giroux, 2009); the experiences of international students (e.g., Duclos, 2011; Karram, 2013; Kenyon, Frohard-Dourlent, \& Roth, 2012); student and faculty mobility (e.g., Knight \& Madden, 2010; Miller \& Blachford, 2012); and north-south partnerships (e.g., Larkin, 2012; Leng \& Pan, 2013). The last topic has been critically analyzed in great detail in two recent doctoral theses (Jorgenson, 2014; Larkin, 2013).

In addition, there is a small but growing body of research from Canadian scholars on study abroad and ISL, which are examples of specific internationalization strategies (Jorgenson, 2010; Larsen, 2014; Larsen \& Gough, 2013; MacDonald, 2014; Pluim \& Jorgenson, 2012; Sharpe \& Dear, 2013; Taraban, Trilokekar, \& Fynbo, 2009). Most of the recent Canadian research on north-south partnership, study abroad, and ISL is critical in nature and draws upon post-colonial theory to interrogate assumptions about the value and benefits of these internationalization initiatives. Another commonality amongst much of the Canadian research on internationalization is the use of the concept "global citizenship," which has been deployed critically by Garson (2013), Hanson (2010), Jorgenson (2010, 2013) and myself (Larsen, 2014), as well as Lynette Shultz, Ali Abdi, and George Richardson (2011) in their edited collection on global citizenship education in higher education.

Some of the literature above refers to particular internationalization policies, but they are not the specific foci of those studies, unlike the broader, policy-oriented and conceptual internationalization literature. For instance, Glen Jones (2009) and Roopa Desai Trilokekar (2010) have examined higher education policy and foreign policy, respectively, in their analyses of internationalization within Canadian HEIs. Kumari Beck's work $(2009,2012)$ stands out for its conceptual and theoretical contributions to our understanding of internationalization and higher education. Overall, the conceptual research is extremely valuable in assisting us to understand, at the policy level, the various rationales, motivations, and ideologies associated with internationalization. However, what these conceptual studies often neglect are the complex and often contradictory ways that internationalization policies get played out on the ground, which can be better understood through case study and empirical data.

Beck (2012) herself asserted that there are key gaps in Canadian research related to the "perspectives, practices, and experiences of participants engaged in internationalization" (p. 136), and Glen Jones (2011) noted the absence of either comparative data or case studies on institutional experiences. A number of recent doctoral theses that critically examine internationalization in specific Canadian universities (e.g., Garson, 2013; Jorgenson, 2014; Khorsandi, 2014; Larkin, 2013) are exceptions to these claims and suggest a new direction for internationalization research in Canada. The present study attempts to build on this recent work by these (and other) emerging internationalization scholars in Canada by teasing out the details of one internationalization initiative through a case-study meth- 
odology. Specifically, this study examines an internationalization initiative that intersects the topics explored in isolation from one another in the existing literature, such as northsouth partnerships, student and faculty mobility, ISL, and international research collaboration. Studying the multifaceted nature of this initiative provides an excellent opportunity to understand the complexities of internationalization in Canadian higher education.

\section{Theoretical Framework}

A number of Canadian researchers, especially some emerging scholars such as Allyson Larkin and Shelane Jorgenson, have drawn upon post-colonial theory in their critique of internationalization policies and practices. This study builds upon that work by deploying post-structural theoretical tools from Michel Foucault (1980) and Patti Lather (1991), as well as post-colonial theory from Edward Said (1979) and Gayatri Chakravorty Spivak (1990). Post-colonial theories are particularly fitting for studying internationalization initiatives that take place in former colonial settings, such as Tanzania, where centre-margin colonial relations are often reinscribed through well-intentioned international research and service programs. Following Foucault and Lather, I attend to the voices of those who are on the margins, such as students and host-community members, who have been silenced in contemporary discourses around internationalization. Post-structural and postcolonial theorists direct our attention to many different accounts/stories and interpretations about why and how we act and think in particular ways. Nothing is viewed as being self-evident. Rather, the researcher is called upon to question taken-for-granted assumptions and develop a healthy sense of scepticism, or what Jean-François Lyotard (1984) called an "incredulity towards metanarratives." As Lorilee Sandmann, Tami Moore, and Jocey Quinn (2012), who research community service learning, explain:

Postcolonial theory provides a specific perspective for the (re)reading of communityuniversity partnership narratives. By surfacing underlying power structures and suggesting opportunities to reinterpret this data, considering the relationships between center and periphery offers an interesting new understanding of what it means, and what is possible, when researchers work with local communities (pp. 35-36).

\section{Methodology: Case Study}

Despite the continued privileging of positivist approaches to educational research, case study is now viewed by many as a legitimate research methodology to deepen our understanding of complex social phenomena in contemporary contexts. For this study, I draw primarily upon the work of Robert Stake (1988), who defines case study as "a study of a bounded system, emphasising the unity and wholeness of that system, but confining the attention to those aspects that are relevant to the research problem at the time" (p. 258). Of additional relevance are Yin's (2014) contentions that case-study research is determined by real-life contexts, and that the boundaries between phenomenon and context are not always clear.

This study is based on the case of North Goes South (NGS), an initiative established in 2003 by Johnstone University as the institution's community response to the HIV/ AIDS crisis in Africa. NGS began as a knowledge and technology transfer initiative whereby knowledge on setting up probiotic yoghurt kitchens, procedures for making yoghurt, 
and business and marketing information and skills were transferred from the university, initially to Tanzanian women involved with the Sawa Women's Rights Organization, in Mwanza. Today, the project involves many individuals in Tanzania, Rwanda, and Kenya, including the women who work in the kitchens, lab technicians, and those who work at the partner organization, the East African Women's Network (EAWN). Since 2004, over a dozen Johnstone faculty members from a wide range of academic programs have travelled to East Africa to conduct research and oversee their students who are involved with NGS. To date, more than 60 students, from every faculty in the university, have participated in NGS service-learning internships, most which last at least three months. In addition to the kitchens, the NGS project also includes two Tanzania-Canada school twinning arrangements, one secondary and one primary.

Case-study methodology provides the potential to understand the complexities of contemporary initiatives and events that require in-depth analysis (Yin, 2014). In this respect, the methodology is particularly fitting for studying a multifaceted internationalization initiative such as North Goes South, which is comprised of different components: international research collaboration; north-south partnership; international school twinning; and ISL. This case study has not only different dimensions but different play (e.g., students, faculty, host-community members), whose roles and expectations vary over time and place." Furthermore, this study is an example of what Stake (1994) calls an instrumental case study, in that it involves closely examining a particular case to gain insight into the larger issues concerning internationalization in higher education and thereby contribute to theory-building in the field.

\section{Data Sources}

Case-study researchers recognize that many variables operate in a single case, so capturing the implications of these variables requires more than one tool for data collection, as well as many different data sources. This study is based on qualitative research methods and includes three different sources of evidence, collected between 2012 and 2013. The first consists of documentary sources, such as the university's Strategic Plan for Internationalization (2009-2012). Other documentary sources include information publicly available on the university website and the NGS website, such as student-intern reports and blogs. The second data source consists of field notes written by the researchers involved in the study. These are my personal, reflective notes as well as the field notes of the research assistants who carried out the work in Tanzania. The final data source consists of interviews with three groups of participants: university student interns, university faculty, and members of the host community in Tanzania. These multiple and diverse sources of evidence provide concurrent validity (using multiple sources and kinds of evidence to address the research question) and convergent validity (triangulating data). I have drawn upon a number of different data sources to enhance the validity of my findings. In addition, it is worth noting the specific need to go beyond the collection of website data, such as university policies, in order to understand internationalization. While assessing online information is relatively easy, it does not provide us with a full and detailed picture of internationalization processes and practices. As Anat Cohen, Miri Yemini, and Efrat Sadeh (2014) note when explaining the limitations of their own web-based analysis of internationalization in Israeli teaching colleges: "It is possible that not all internationalization processes taking 
place at the institution are reflected on the [web]site, or alternatively, international activities may be exaggerated for the purposes of publicity and prestige" (p. 36).

\section{Participants}

Purposeful sampling was used to choose research participants from three different groups. In total, 52 participants were interviewed for this study (34 females and eight males). The first group consisted of nine Johnstone students who participated in NGS internships to East Africa in 2012. Four students had placements in Tanzania, three in Kenya, and two in Rwanda. There were two males and seven females, ranging in age from 21 to 47. One defined herself as being of African/African Canadian ethnic background and the other eight as European/White. Two were pursuing their PhDs, two master's, and three undergraduate degrees, across a variety of faculties.

The second group consisted of four university faculty members and the Internationalization Vice-Chair, a senior administrative position at the university. The criterion for inclusion was a demonstrated commitment to the NGS project through research, teaching, or service with the NGS steering committee. I included myself within this group, as I am a faculty member at the university, and I have had extensive involvement with and commitment to NGS by serving as a steering committee member and providing financial support to the program. Three of the four faculty members, including myself, have sat on the NGS steering committee, two are scientists whose research on probiotic yoghurt is at the heart of the project, and all four have research agendas relating to NGS and support graduate students who have participated in NGS internships.

The final group of participants consisted of community members in Mwanza, Tanzania, who hosted the university students participating in service learning internships each year. Eighteen women who worked in the community kitchens and 10 individuals who had contact with the student interns between 2005 and 2012 were interviewed. The 10 individual community members included: the headmasters and a deputy headmaster from each of the two "twinned" schools; two Sawa employees; the EAWN Director, who co-ordinates activities for the project in Tanzania; two people working in local shops the students frequented; a local taxi driver; and a street leader.

\section{Research Instruments}

I conducted pre-internship surveys, post-internship surveys, and interviews with the student interns, aiming to understand students' experiences of their internships. I also conducted short, semi-structured interviews with the university faculty and the EAWN Director. I was interested in understanding their experiences with NGS, the impact of the project on them, as well the values that motivated them to be involved in this initiative. I have also drawn upon my reflective research notes written throughout the data collection and analysis stages of this study. My interview with the Internationalization Vice-Chair was aimed at gaining a deeper understanding of the university's internationalization policies, as well as how, if at all, she saw the NGS project aligning with the university's strategic plan for internationalization (SPI). Interviews with host-community members were aimed primarily at understanding the impact, benefits, and challenges of having the student interns live in their communities during their internships. Three research assistants 
in Tanzania carried out these interviews with the help of a local interpreter. The research instruments that were deployed align with the interpretivist tradition of research in that they are geared towards seeing the situation through the eyes of the participants.

Finally, case-study researchers are often privy to confidential or sensitive material and therefore must be clear on research ethics, their own stance with respect to disclosing sensitive data, and protecting people at risk (Cohen, Manion, \& Morrison, 2011). For these reasons, all organizations and participants that I refer to in this study are pseudonyms. Participants were informed that participation was voluntary and that they could refuse to answer any questions or withdraw from the study at any time without affecting their position or status with the university or NGS.

\section{Findings}

In this section, I outline the main findings from my study. To reiterate, the study was guided by a desire to probe the perceived impact of NGS on students, faculty, and Tanzanians involved in the initiative. First, I describe the official discourse about NGS as an exemplary model for internationalization. Next, I summarize the key findings from my interviews with faculty members about what motivated their involvement in this initiative and what they perceived to be the benefits associated with NGS. I then present the findings from my interviews with the students and Tanzanian community members on the same topics.

\section{The Official Discourse: North Goes South-A Model for Internationalization}

Johnstone University has embraced internationalization as a key strategic planning priority, which has been reflected in each of its three SPIs since 2003. NGS is held up as an exemplary model for internationalization at the university. The university's Strategic Plan for Internationalization 2009-2012 states: "Research at Johnstone on the beneficial effects of probiotic yoghurt has been a cornerstone of the award-winning North Goes South project". Moreover, the university's Internationalization Vice-Chair noted that NGS is viewed as a model of internationalization at Johnstone. During her interview, she spoke about her ideas regarding the need to engage responsibly in international development activities, and in this respect believed that NGS provides a good model, as at its core is a "real sense that we have to be responsible in our international development activities." These comments reflected those of the former Vice-Chair, who noted in 2007 that the university's "activities in East Africa are also a concrete demonstration of this university's commitment to internationalization, and enhance [the university's] reputation as a global player with much to offer."

Faculty members interviewed for this study also viewed NGS as a model of internationalization at the university. Dr. Sharon Bouri, the professor who donated the strand of Lactobacillus for the probiotic yoghurt formula, put it clearly: "[W]hen it comes to internationalization, what is [our university] if it's not North Goes South? There's nothing else. What else are we famous for at our university but North Goes South? Nothing . . North Goes South is our flagship.” And Dr. Labelle, who has accompanied her students to Tanzania to learn about global health promotion, noted that NGS "has been an important exemplar for students ... for us to learn collaboratively how to partner with others."

Dozens of examples from the university's website demonstrate that the university views NGS as a model for internationalization. For example, the Results of Johnstone 
University's Strategic Plan for Internationalization, 2009-2012, East Africa Report has an entire page devoted to the impact/reputation of NGS, with claims that the project is "the only initiative in a Canadian institution of higher learning with university-wide participation by faculty, students and staff", as well as the fact that over 50 research papers about probiotics and 10 business cases based on NGS have been published. The university has also publicized that NGS was one of four winners of the 2006 Scotiabank-Association of Universities and Colleges of Canada (AUCC) Awards for Excellence in Internationalization. The AUCC (2006) report Preparing Students for a Global Future: Internationalization Initiatives in Canadian Universities commends Johnstone's emphasis on exposing university students to international experiences and developing opportunities for the international engagement of students in research and academic exchange programs. The report further notes: "The practical, sustainable nature of the work and the hands-on experience gained by the student interns have greatly enhanced appreciation for the plight of African people as they struggle with overcoming the problem of AIDS. ... The project has also demonstrated that it is possible to create a partnership between university faculty, students and staff to address international issues of concern" (p. 11).

\section{Impact on Faculty}

In line with this official discourse, faculty members interviewed also spoke about the personal benefits of being involved with NGS. The primary motivation was the desire to be involved in an international project that could improve people's lives. Dr. Henry Wu spoke about how important it was for him to be involved in "a community project and empowering women to be involved in the community and also improve their health." Dr. Sharon Bouri spoke about her family connection to Africa and the desire to do "something in science that helps people." Moreover, they viewed their involvement as a pathway for learning about cultures other than their own, different languages, how to work collaboratively with others, and enhanced ways of thinking about their specific research areas. Dr. $\mathrm{Wu}$ spoke about the personal satisfaction that came with being involved in a project that improved people's nutritional status based on research that he has been involved in for many years. Dr. Bouri noted that her involvement with NGS allowed her to learn from East Africans: "They are educating us (and the wider scope of people here) to realize that this is another part of life that they just don't see every day."

Opening doors for students interested in international learning opportunities was another motivation for faculty to be involved in the project. As Dr. Bouri explained:

The students are always very interested in Africa, and many of them like to go there. I usually tell them about the projects in Africa, because I think it grounds people. ... So I am trying to let students know there's another world out there; plus the research has to be relevant [to humans], in my view, which a lot of research is not.

Dr. Wu found it personally very satisfying that NGS provided not only international research opportunities for his students but also broader learning opportunities:

It has been a very rewarding project for me and also for my students; students who have gone to Africa always come back with a very positive attitude and want to do more for world health and the world economic situation. 
Dr. Denise Labelle, who accompanied students from her global health class to Tanzania in 2012, was motivated by her desire to provide her students with an international project base for their coursework.

Interestingly, the faculty members did not emphasize the research opportunities that NGS provided them with. Dr. Bouri forcefully explained that her initial motivations for being involved in NGS were "certainly not" for research purposes, but this changed over time as new opportunities arose:

Now I think probably the research component is quite a factor in it because I think we can do things there potentially and get grant money to do it, where when I first started there was no interest in funding whatsoever.

While all of the faculty members underplayed the importance of NGS in opening up research opportunities, the fact of the matter is that NGS has provided many such opportunities for both faculty and students.

\section{Impact on Students}

The student interns who participated in the study were asked a number of questions pertaining to the impact of their involvement with NGS. Data collected show that the NGS internship provided them with many new skills, knowledge, and attitudes (Larsen \& Gough, 2013; Larsen, 2014). First, students learned a number of skills, such as negotiation, bargaining, and problem solving. They made efforts to participate in local community life, and a handful tried to learn the local language. Interns also talked about their experiences of shopping in the local markets, eating local food, and spending time with locals, which helped to enhance their cross-cultural understandings of the people with whom they were living.

The majority of the students spoke about learning to be more patient and flexible. Melody, the EAWN Director, noted that many of the students learned a great deal about flexibility and "different strategies for coping with difficulties when working in another country, because it is stressful at times dealing with another culture, misunderstandings, language barriers and all these types of things." Through the internship, many came to appreciate the emphasis on community relations in the East African settings where they were placed. For example, Sam and Vera talked favourably about and participated in a community service initiative in Rwanda called Umuganda, in which the last Saturday of every month was set aside for everyone to engage in volunteer community work. Some interns spoke about the relationships they developed with locals. After her internship, Rhonda said, "I think that definitely making friends was a huge part of what I did there. I feel like I made really strong bonds with a few of the women in the kitchen." One cultural aspect most of the interns remarked upon was the work ethic and resilience they witnessed amongst the East Africans they met. Lara remarked:

I'm so grateful for their assistance ... so impressed with their skills. It's probably a cliché to say that I learnt more from them than they did from me. I think that what they do just to get through the day is amazing. They're really remarkable. There's a sense of community; there's a sense of inner strength.

Finally, students also learned much about geographical, political, religious, and crosscultural differences within and across different East African countries. 


\section{Challenges Students Experienced}

Despite these positive outcomes, the Canadian students also indicated that they had faced a number of challenges during their involvement with NGS. They spoke about feeling isolated and lonely during their internships, especially those who lived in the more rural settings in Rwanda and Kenya. Some students felt stressed about their own safety and expressed their worries and fears about thefts. In one case, a student had her money stolen from the apartment that had been set up to accommodate interns based in Mwanza. Students expressed exasperation at not being able to contact the NGS administration in Canada to deal with these and other problems concerning their well-being and safety.

Many of the students experienced long delays and barriers in moving ahead with their research projects. One student fell into a depression while waiting for ethics board approval to begin her study. Other students noted their frustration at trying to conduct their research studies when participants did not show up as planned, or supplies ran out. Some students spoke about having to wait for long periods of time for others to show up at arranged meetings or get-togethers. Others spoke about the irritations involved in waiting for processes that affected their status in the country to move forward. Edna, for example, experienced unnecessarily long delays in trying to get her visa renewed in Tanzania, and two students based in Kigali found that it took significantly longer than anticipated to get the kitchen established there.

Finally, although many of the students felt they were entitled to special treatment as guests in a foreign country, they also felt irritated when treated as if they were privileged. Some students were annoyed at assumptions (held by "locals") that because the students were white, they were more privileged. This led to many instances of being asked for money or other resources they did not feel able to give, or being charged significantly more for items in the market than the locals were expected to pay. They also expressed exasperation over being called mzungo (white person) by local people. Being judged by the colour of their skin was something the majority of the interns had not previously experienced, and it made them feel very uncomfortable, reflecting their own lack of awareness of their racial background and privileges as white, middle-class, Canadian university students.

\section{Impact on the Tanzanian Host Community}

The data collected for the study, both documentary and interview, show benefits associated with the NGS project for the East African communities where the kitchens are based. This is particularly the case for the women who work in the kitchens, those who supply the milk used to make the yoghurt, the beneficiaries (people living with HIV/ AIDS), and others who consume the yoghurt. At the time of this study, there were 10 community kitchens operating in and around Mwanza, Tanzania, one outside of Kigali, Rwanda, and one in Oyugis, Kenya. There were a total of 64 people who were members of the Mwanza-based kitchens in 2012, and 748 beneficiaries. The average monthly profit of the kitchen groups (i.e., after expenses) was 530,000 Tanzanian shillings ( $\$ 355 \mathrm{Ca}-$ nadian), which is high given that the average per capita income in Mwanza is about \$21 per month, and even lower for women (Mwanza Children's Network, 2013). Beneficiaries noted the following personal benefits from consuming the yoghurt: positive changes in their quality of life, including their health and well-being; increased confidence; a more 
positive, optimistic outlook; and a sense of hope. Some also noted that consuming the yoghurt decreased the painful side effects of the medications they were taking, as well as other health problems they had previously experienced.

Interview data with Tanzanian host-community members indicate that they learned a number of skills from the Canadian student interns. First, the women working in the kitchens, and the EAWN Director, spoke about learning how to make the yoghurt, including the proper procedures for boiling the milk and for ensuring hygiene and quality control. Second, women working in the kitchens learned basic business skills, such as accounting, customer relations, packaging, and marketing. Interns also worked with EAWN staff to help with strategic planning initiatives, time management, finances, and the distribution of promotional materials. Third, the project benefitted local community members by helping some of them to learn basic English skills. Some either took part in English lessons with the interns or simply picked up basic phrases from them. Tanzanian participants also noted that they learned computer skills from the students, such as how to use email and Skype. Finally, some cross-cultural learning also took place amongst the Tanzanian participants; however, this knowledge was limited, and much of it reflected very basic, stereotypical ideas, such as Canada being a big and cold country, and Canadians being lovely, friendly, unprejudiced people.

Overall, the Tanzanian participants indicated a general sense of appreciation for the NGS project, especially for the interns involved. Many perceived the interns as sympathetic, co-operative, hardworking, motivated, and committed to their work. Participants also viewed many of the interns as open-minded and interested in learning. In the interviews, they used words and phrases such as "co-operative," "being in communication," "listens to people," "likes to socialize," "working hard," and "working together." Moreover, nearly all of the Tanzanian participants recalled particular interns who had taken the time to integrate themselves into the community by staying for longer (six months or more), learning Swahili, and involving themselves in the community by participating in local events such as festivals and funerals.

\section{Challenges the Tanzanian Community Members Experienced}

Despite these positive accounts about the value of the NGS program, some of the Tanzanian participants also reflected upon certain limitations and problems of the initiative. A few noted problems with student interns who behaved in culturally inappropriate ways. Two men interviewed remarked about the closeness between some of the male and female interns, which was viewed as inappropriate in the Tanzanian context. As Afla explained, "There are differences in the Tanzanian cultural context. ... When [the students] come, they are too close. Living together. Eating together. Everything they do. They are too close. Everything they do." Others remarked upon interns wearing appropriate clothing (e.g., by donning short pants or "underwear" in public), or students' lack of awareness about the importance of showing respect when greeting elders.

Language was also a barrier between the students and the Tanzanians. Only two of the nine interns were able to have some very basic conversations with local people in the local language. The others learned just a few basic phrases, such as how to say hello, good morning, and goodbye. Many of the interns noted that their limited abilities in the local language restricted what they were able to do. Some said they were not motivated to learn 
the local language(s), either because most locals spoke to them in English (or French, in Rwanda) or the local languages were difficult to learn. The Tanzanian participants also spoke about the problems they faced in dealing with Canadians who did not speak Swahili. The taxi driver said that it was difficult to provide her services when the interns could not explain to her where they wanted to go; the shop manager said that language was a problem when the interns were not able to express what they needed in Swahili. One of the interns remarked on the same problem:

The majority of the people in the markets and stores do not speak any English whatsoever, same with a lot of people you meet on the street. I hate going into a store not being able to communicate on a simple level to be able to get my shopping done.

When probed, a few of the women who worked in the kitchens also spoke about the problems they faced trying to communicate with the students. They admitted their need for a translator to be present-but this service, which was generally provided by EAWN staff, turned out to be burden for that over-stretched organization. EAWN's Director, Melody, explained that students' lack of knowledge about the local language

creates a barrier in working with all the people at our kitchens because they constantly require some sort of translator, which is fine because even if they learn some Swahili they would still need that, but it creates a distance in being able to create a relationship when they are not trying at all.

At the heart of these problems, according to Melody, lay the students' sense of entitlement, an issue I return to in the discussion section below.

These findings echo those from Larkin's (2013) study, about the misalignment of north-south partnerships when local agendas demand tremendous efforts from host partners who are expected both to accommodate the needs of visiting students and to mitigate the damaging consequences of their presence.

\section{Discussion}

At the level of official rhetoric (as evidenced by university policies and website information), NGS is an award-winning model of a responsible internationalization partnership project. Material on the university's and NGS's websites and in the university's newspaper, as well as data from interviews with the Internationalization Vice-Chair and key faculty members, all suggest that NGS operates as an exemplar for other education institutions and interested parties. Moreover, interviews with faculty, student interns, and Tanzanian community members show that many benefits are associated with the NGS project. The kitchens have provided a nutritious product for the beneficiaries, as well as incomes and a sense of community for the women working in them. The women have learned much from the Canadian interns in terms of skills related to yoghurt production, business, and marketing. The students also spoke about the skills, knowledge, and attitudes they were exposed to during their internships. Finally, the students and faculty noted the personal satisfaction they felt from "making a difference" in the world. 
This, then, is one perfectly reasonable "reading" of the data. However, I would like to suggest another, quite different, set of conclusions. The above are based on what I would call a surface reading of the data. Here, I engage in a process of digging more deeply through the data so as to present another, contradictory reading that was not as apparent upon my initial reading. Kathy Charmaz (2006), in writing about grounded theory, explains that as researchers, we should "not force preconceived ideas and theories directly upon our data" (p. 17). I realized that as someone intimately connected to the NGS project by being a steering committee member and a financial supporter, I had initially forced some of my preconceived ideas upon the data. This points to the complications of being closely involved in the research one is conducting. Yet, simultaneously, my involvement allowed me opportunities to uncover another story about NGS, one not as flattering as the official discourse would suggest. This alternative account only emerged through a long, deeply reflective process as I read and re-read the data with an eye to the power relations that operated in such a way as to hush or silence critics of the program.

Melody, in particular, provided many insightful reflections about NGS during her interview. Hers is a particularly interesting case and worth further attention. Melody was a former Johnstone student who had completed her own NGS internship in 2007, whereupon she decided to stay in Tanzania, volunteering and working for local NGOs and assisting with the formation of EAWN. Although she is of white European background, she functions as a bridge between the Global South and the Global North, having been fully immersed in Tanzanian culture for the last seven years, including speaking Swahili. Despite taking on a leadership position with EAWN, she still struggled with the feeling that her opinions were not taken seriously by the NGS administration. Her words-the most direct of any of my "Tanzanian" participants-hinted at the problems within the NGSEAWN partnership. For example, when asked what could be done to improve the project, she stated that the interns "do so much research and collecting information and leave and then they [i.e., the community partners] never hear anything from them and they don't get any information from the studies that they have done." Tanzanian participants I interviewed also alluded to this issue and to a desire to be informed about the results of studies carried out in their communities by NGS researchers. Furthermore, one employee at the Mwanzan medical lab that produced the probiotics was involved in research leading to the publication of an article (by one of the NGS faculty members) that did not include his name. This left the lab technician embittered about the idea of research partnerships with NGS. So, while NGS provides many research opportunities for both students and faculty, we must ask ourselves: Who benefits? In this instance, the local researcher did not, and it is unclear how other members of the community benefitted either.

Officially, there is much talk about the research partnerships that have developed through NGS, but the above evidence alludes to the possibility that these partnerships are not mutually beneficial to all parties involved-a point that Larkin (2013) also makes in her doctoral thesis on a north-south partnership involving a Canadian university and Tanzanian partner organizations. She explains that the findings from her study "challenge the prescriptions of internationalization that conceive of N-S [i.e., north-south] partnerships as neutral engagements. This N-S ISL partnership struggled to mediate relations of power and authority that were significantly complicated by the absence of awareness of race, culture and history" (p. 175). 
Moreover, Larkin's discussion about the impact of the "Mzungo Effect" aligns directly with the findings of my study. The ISL students in her study were unaware of their whiteness and what it signified. Larkin's claim that the effect of whiteness is an under-theorized dimension of north-south partnerships points to the very real need for further research in this area.

These problems stem from patronizing perceptions of the Other, rooted in colonizing discourses (Said, 1978) that, in this case, position East Africans as less intellectually competent. For instance, Melody described in detail an incident that reflected some of the interns' deeply troubling attitudes towards Tanzanians:

I found some of the attitudes of the more negative interns, as I would call them, were really kind of harsh towards some of the staff members in terms of language. They would speak to them in English and try to do their best; but I even overheard some of them like saying, "Oh! She doesn't even know how to speak English properly," and that was overheard by [the staff member]. And she actually had the courage to go up to them and said, "I am really sorry but English is not my first language, and if you have something to say to me you can say to me and I would like you to tell me, maybe you could ask me in a different way and I can explain to you." She was really hurt by that, and that's from interns who didn't even make an effort to try even learning greetings in Swahili. So I think the sense of entitlement was a big issue relating to language.

The sense of entitlement about which Melody spoke was not held equally by all of the interns. Indeed, Melody, operating as a bridge between the two cultures, was in a good position to grasp the subtle differences between and amongst the interns and others involved in NGS. She could see that some interns

really value[d] the Tanzanian people they were working with because they got to know them on a personal level and saw their strengths, abilities and capabilities .. . but others [had] a more negative attitude toward Tanzanians just by their general comments: "I don't understand why Tanzanians are like this" and pointing out the negative aspects of the culture.

Indeed, there were many differences in intern experiences, which I only discovered by digging more deeply through the data. In re-reading the student data, I realized I had not initially coded for race, age, or previous international experience. Yet, it appeared that the students who were older than 30, racialized, and/or had previous international and development experience had a much more critical and analytical understanding of their experiences. Hence, age, race, and prior experiences emerged as variables that demanded further analytical attention.

The students who appeared to reflect most deeply upon their experiences, privileges, and understandings of difference were those who were already critically inclined. The internship did not shape their complex and critical views about development issuesrather, it reconfirmed what the more mature students had learned previously, whether through first-hand experiences in the Global South, through reading critical literature about global issues, or through personal experiences dealing with race and other forms of 
privilege. For example, Carol, who self-identified as an African Canadian, noted that her goal in participating in the internship was to produce an informative documentary about development issues from an African perspective. Why then did she choose not to participate in the post-interview part of my study? Her silence spoke volumes to me about her experiences as an intern of African Canadian background, and the complexities of race and other aspects of identity that shape students' international experiences.

And then there were the silences amongst the Tanzanian participants. The majority were very reluctant to express any dissatisfaction with NGS, despite reassurances from the researchers that constructive criticism to help improve the project was welcome. This is unsurprising given that most of the Tanzanian participants benefit financially and in other ways from being involved with NGS, and the sheer weight of the power imbalance was not in their favour. One of the university researchers, when reflecting upon the challenges of carrying out the study in Mwanza, noted that the formalities associated with reviewing the letter of consent and ethics protocols put the women off and made them feel as though they were doing something wrong. Furthermore, community members' reluctance to speak critically about the effects of hosting international students, given the economic stakes involved, has been noted by other researchers, such as Schroeder, Wood, Galiardi, and Koehn (2009), who assert: "The economic stake of having visitors return may be very high, so there is little incentive [for host community members] to give negative reviews of the local experience of students and the impacts of their presence" (p. 143).

Charmaz (2006), discussing the process of conducting interviews, notes that while in some cases respondents' stories may "tumble out," in others, respondents may not be as forthcoming. If the latter, it usually takes significant effort to discover the "subtlety and complexity of respondents' intentions and actions" (p. 34). That becomes a very difficult challenge when operating in unfamiliar cultural settings, and almost impossible when conducting research in situations where the power imbalance is so heavily skewed in favour of the Western researcher. For the most part, the students and faculty I interviewed were more forthcoming than the Tanzanian participants. However, many of the students only spoke openly and critically about NGS to me after the digital recorder was turned off and the "official" part of the interview over. They shared with me their frustrations and disappointments with NGS and their fears that they could not speak out openly, in public (or on tape), about their concerns and anxieties. After hearing these off-the-record "counter-stories," I went back to the transcribed interview data and reread it through a different lens. I could see the criticisms of NGS and their experiences in ways that I had not seen in my first reading of the data. For example, I reread this section in the transcript of Lara's interview in an entirely new light: "I think that it's emotional when I see things that aren't going well there, that might be directly related to Canada and ... I think it can be a little disempowering sometimes." I read this, and I heard her hesitancy to assert her own voice, instead using words like "I think" and saying it was "a little" disempowering. These snippets of interview data are glimpses into another way to make sense of the data, a more complex and messy way of understanding this internationalization initiative.

Michel Foucault (1980) suggests we turn our attention to the views of those who have been "out of sight" in history: those who are marginalized because they are regarded as "abnormal." He refers to truths expressed by the marginalized as low ranking, subjugated, or disqualified. I would argue that the voices of the local Tanzanians-including 
the women working in the kitchens, Melody, and some of the interns-are what Foucault call "disqualified" or "subjugated." These disqualified knowledges, as Foucault writes, are what enable us to perform critical work:

[T]hrough the re-emergence of these low-ranking knowledges, these unqualified, even directly disqualified knowledges . . . and which involve what I would call a popular knowledge though it is far from being a general commonsense knowledge, but is on the contrary a particular, local, regional knowledge, a differential knowledge incapable of unanimity and which owes its force only to the harshness with which it is opposed by everything surrounding it- that it is through the re-appearance of this knowledge, of these local popular knowledges, these disqualified knowledges that criticism performs its work [italics in original] (p. 82)

NGS is a powerful "machine" in that it has come to be viewed by the top levels of administration at the university, by faculty members who are involved in the project, and by those on the steering committee as a model and flagship of internationalization. To criticize the official discourse about NGS is to say the unthinkable-hence Foucault's (1980) assertion that disqualified knowledge "owes its force only to the harshness with which it is opposed by everything surrounding it" (p. 80). This explains why most of the students could not speak out about what they considered serious problems associated with NGS, why Melody felt silenced by the NGS administration, and to some degree why local participants in Tanzania were reluctant to criticize a program that brought financial benefits to their under-resourced communities.

Yet, these voices need to be recognized. Like Patti Lather, I believe it is important to make room, in meaningful ways, for those on the margins. In her introduction to Getting Smart, Lather (1991) explains: "I write in a time when the formerly unsaid/unheard are becoming increasingly visible and audible. Historical 'others' move to the foreground. Centers and margins shift . . . brought about by the silenced coming to voice" (p. xix). Spivak $(1985,1988,1990)$, on the other hand, has cautioned regarding the possibility of colonized or marginalized people being able to speak-and, more significantly, to be heard by those in power. She has argued that the voices of the subaltern are in danger of forever being covered up by those who are describing them. However, Spivak (1990) also directs attention to the willingness and need for those at the "centre" to listen and hear what is being said:

For me, the question, "Who should speak?" is less crucial than "Who will listen? . . . [T]oday ... the real demand is that, when I speak from [the] position [of a Third World person], I should be listened to seriously, not with . . . benevolent imperialism . . . because I happen to be an Indian or whatever. . . . A hundred years ago, it was impossible for me to speak, for the precise reason that makes it only too possible for me to speak in certain circles now. (pp. 59-6o)

I was guided through this research study with a desire to better understand the inner workings of an internationalization initiative that I was implicated in as a steering committee member, financial supporter, and researcher. I found it difficult to carry out this research, especially as participants spoke "off the record," and I subsequently saw the negative (and 
troubling) effects of the initiative. I was forced to engage in a self-reflective process about my position as a white, Canadian researcher engaged in research with participants from the Global South. Given that I am firmly situated in an elite role as a university researcher, I realized the risk of distorting the perspectives of the Tanzanian community members and wondered whether I could even begin to suggest speaking/writing on their behalf, as Spivak $(1985,1988)$ cautions. Other emerging internationalization scholars in Canada (e.g., Jorgenson, 2014; Larkin, 2013; MacDonald, 2014; Sharpe \& Dear, 2013) also note the importance of reflecting upon the subject position of the researcher, especially when one is a white, European researcher doing research involving the Global South. Moreover, I contend that we (in the centre) who recognize our power and privileges need to actively mobilize these to make a difference in the lived experiences of those on the margins.

Doing so can help to shed light on the gap between official discourses of internationalization and what these policies look like in practice. The problem is not simply one of perception-that some individuals perceived the initiative as valuable and others do not. The heart of the problem actually lies in the origins of the NGS initiative: a belief that the HIV/AIDS crisis in Africa could be addressed through the transfer of knowledge from a Canadian university to a group of women involved with a community-based program in Mwanza. The unproblematized, deficit-based foundation established, from the beginning, an unequal relationship between those at Johnstone, who are considered the bearers of knowledge and skills, and local partners, who are not. In some ways, then, the relationship between NGS and local partners is reflective of a partnership based on the dominance of Western hegemony. This concern is particularly pertinent in partnerships negotiated between HEIs and community organizations or individuals, where, as Larkin (2012) explains:

there are issues regarding each partner's available resources, different operational frameworks and goals for project outcomes. In fact, many programs that can be classified as international development and cooperation are formed through informal channels, and are often the results of professional contacts of particular faculty members and, in contrast to other institutional partnerships, they are subject to little oversight and ethical evaluation. (p. 81)

The gap between the official discourse of internationalization at Johnstone University, on the one hand, and the damaging effects of the initiative on participants, on the other, also aligns with Khorsandi's (2014) findings from his doctoral study on internationalization policies at a Canadian university. His study, involving interviews with university administration and faculty, led to the conclusion that while in theory the internationalization of higher education is supposed to be about educating critical, responsible, and engaged global citizens, in practice it is about commercializing research, generating revenue, and building an international reputation. North Goes South is an excellent example of how a university can utilize one of its international initiatives to build its national and global reputation, even at the expense of those who are purportedly their "partners" but who remain at the margins of Canadian university internationalization strategies. 


\section{Conclusion}

This study aimed to provide a rich portrait of the practices of internationalization, by studying, in depth, one particular internationalization initiative at a Canadian university. Specifically, this was a study of one international initiative in order to broaden our understanding of the wider phenomenon of internationalization in higher education. Qualitative research methods were used to understand the impact of the project on various stakeholders, including faculty, student interns, women working in the kitchens, and other local community members involved NGS. While I was motivated by a desire to understand the broader impact of the project, this was not a project evaluation study per se, and the conclusions here are not geared towards providing specific recommendations on how to improve the project. Rather, the aim was to tease out the complexities of how those involved in this initiative have experienced internationalization in their day-to-day lives.

NGS is held up by the university, senior administrators, and key faculty as an exemplary model for internationalization. This constitutes the official discourse on NGS. My study shows evidence that this is true for some of the stakeholders involved in the project. Some faculty derive tremendous satisfaction from being involved and assisting their graduate students with research-based internships. Most of the student interns I interviewed also derived personal and professional benefits from participating in internships for three months or longer in East Africa. Interviews with host-community membersranging from the women who worked in the community kitchens to local school masters and shop owners-also showed that the project has brought benefits, both financial and skill-based, to members of the local Tanzanian community where NGS is based.

Yet, the project is not without flaws, primarily the initiative's assumption that Canadian universities can solve African problems. The unequal relationship that characterizes the north-south relationship is reminiscent of the colonial antecedents of internationalization in higher education, with foreigners, typically from the West, working in "developing" countries to modernize or fix "backward" societies. The connections between contemporary internationalization initiatives such as NGS, which are based on the honest and sincere desire to "help," sit uncomfortably close to the colonial legacies that constructed dependent-and in some cases destructive-relationships based on binary ideas that positioned the West/European as superior and civilized and the East/“Other" as inferior and uncivilized (Said, 1978).

What more can we learn from this study? In some ways, NGS provides us with a working template for internationalization in HEIs, but as Melody points out, "it's not quite there yet." This study shows that there are many benefits for those engaged in internationalization initiatives such as NGS: university faculty and students, as well as hostcommunity members. However, this study also revealed that those who participated in NGS faced many barriers and challenges that are rarely recognized, let alone publicized, by the university who views NGS as an exemplary model of internationalization. This study points to the crucial importance of pre-departure training for students and faculty engaged with the initiative, training that will focus on a thorough understanding of the socio-cultural contexts within which they will be working. There is also room for improved lines of communication between student interns, partners in Tanzania, and the NGS administrators in Canada. More importantly, however, there is an urgent need to 
shift the project's foundation away from a deficit-based approach to addressing the HIV/ AIDS crisis in Africa, to an asset-based approach that acknowledges the community as possessing valuable knowledge and strengths. This would also shift our thinking away from homogeneous binaries (the university and the community) so as to understand the heterogeneous positions of entities such as universities and communities, and how they can play out their roles in internationalization policies.

\section{Note}

1. Pseudonyms have been used to refer to all organizations and participants in this study.

\section{References}

Association of Universities and Colleges of Canada. (2006). Preparing students for a global future: Internationalization initiatives of Canadian universities. Ottawa, ON: Author.

Association of Universities and Colleges of Canada. (2014). Canada's universities in the world: AUCC internationalization survey. Ottawa, ON: Author.

Beck, K. (2009). Seeking the “inter": Contextualizing, contesting, and reconceptualizing internationalization of curriculum. In J. Nahachewski \& I. Johnston (Eds.), Beyond presentism: Re-imagining the personal, social and historical places of curriculum (pp. 123-137). Rotterdam, Netherlands: Sense Publishers.

Beck,K.(2012).Globalization/s: Reproduction and resistancein theinternationalization of higher education. Canadian Journal of Education, 35(3), 133-148.

Beck, K. (2013). Making sense of internationalization. In Y. Hébert \& A. Adbi (Eds.), Critical perspectives on international education (pp. 43-59). Dordrecht, Netherlands: Sense Publishers.

Charmaz, K. (2006). Constructing grounded theory: A practical guide through qualitative analysis. London, UK: Sage.

Cohen, A., Yemini, M., \& Sadeh, E. (2014). Web-based analysis of internationalization in Israeli teaching colleges. Journal of Studies in International Education, 18(1), 23-44.

Cohen, L, Manion, L., \& Morrison, K. (2011). Research methods in education. London, UK: Routledge.

Duclos, V. (2011). L'intégration universitaire et sociale d'étudiants tunisiens et marocains inscrits dans une université francophone canadienne. Canadian Journal of Higher Education, 41(3), 101-126.

Foucault, M. (1980). Power/knowledge: Selected interviews and other writings: 1972-1977. New York, NY: Pantheon Books. 
Garson, K. D. (2013). Are we graduating global citizens? A mixed method study investigating students' intercultural development and perceptions of intercultural and global learning in academic settings (Unpublished doctoral dissertation). Simon Fraser University, Burnaby, BC.

Hanson, L. (2010). Global citizenship, global health, and the internationalization of the curriculum. Journal of Studies in International Education, 14(1), 70-88.

Jones, G. (2009). Internationalization and higher education in Canada: Three challenges. In R. D. Trilokekar, G. A. Jones, \& A. Shubert (Eds.), Canada's universities go global (pp. 355-369). Toronto, ON: James Lorimer and Company.

Jones, G. (2011, January). Globalizing Canada's universities: An overview. Paper presented at the meeting of the Ontario Confederation of University Faculty Association, Toronto, ON.

Jorgenson, S. (2010). De-centering and re-visioning global citizenship education abroad programs. International Journal of Development Education and Global Learning, 3(1), 23-38.

Jorgenson, S. (2014). (De)colonizing global citizenship: A case study of North American study abroad programs in Ghana (Unpublished doctoral dissertation). University of Alberta, Edmonton, AB.

Karram, G. L. (2013). International students as lucrative markets or vulnerable populations: A critical discourse analysis of national and institutional events in four nations. Canadian and International Education, 42(1), Article 6. Retrieved from http:// ir.lib.uwo.ca/cie-eci/vol42/iss1/6/

Kenyon, K. H, Frohard-Dourlent, H., \& Roth, W. D. (2012). The ambiguities of international student status: American undergraduate students in Canada. Canadian Journal of Higher Education, 42(1), 1-24.

Khorsandi, A. (2014). A critical policy analysis of internationalization in postsecondary education: An Ontario case study (Unpublished doctoral dissertation). University of Western Ontario, London, ON.

Knight, J. (2004). Internationalization remodeled: Definition, approaches, and rationales. Journal of Studies in International Education, 8(1), 5-31.

Knight, J., \& Madden, M. (2010) International mobility of Canadian social sciences and humanities doctoral students. Canadian Journal of Higher Education, 4O(2), 18-34.

Larkin, A. (2012). Implications for Canadian higher education internationalisation policies: Critical considerations on the impact of the shift to knowledge exports from cooperative and development programming. Potentia, 4, 73-86.

Larkin, A. (2013). Internationalizing Canadian higher education through north-south partnerships: A critical case study of policy enactment and programming practices in Tanzania (Unpublished doctoral dissertation). University of Western Ontario, London, ON.

Larsen, M. (2014). Critical global citizenship and international service learning: A case study of the intensification effect. Journal of Global Citizenship and Equity Education, $4(1), 1-43$. 
Larsen, M., \& Gough, R. (2013) Personal and political transformation: Two case studies of a university based international service learning internship. International Journal of Education for Social Justice, 2(2), 109-129.

Lather, P. (1991). Getting smart: Feminist research and pedagogy with/in the postmodern. New York, NY: Routledge.

Leng, P., \& Pan, J. (2013). The issue of mutuality in Canada-China educational collaboration. Canadian and International Education, 42(2), Article 6. Retrieved from http://ir.lib.uwo.ca/cie-eci/vol42/iss2/6/

Lyotard, J. F. (1984). The postmodern condition: A report on knowledge. Minneapolis, $\mathrm{MN}$ : University of Minnesota Press.

MacDonald, K. (2014). (De)colonizing pedagogy: Engaging students abroad. In R. Tiessen \& B. Huish (Eds.), When the world is your classroom (pp. 209-227). Toronto, ON: University of Toronto Press.

Miller, M., \& Blachford, D. R. (2012). A model for a sustainable partnership: Connecting Chinese visiting scholars, the university and the community. Canadian and International Education, 41(1), Article 3. Retrieved from http://ir.lib.uwo.ca/cie-eci/vol41/iss1/3/

Mwanza Children's Network. (2013). The situation facing children at risk in Mwanza. Retrieved from http://www.wabia.net/sites/default/files/pdfs/Hali-Ya-Watoto.pdf

North Goes South (2013). Stewardship Report. September 2013.

Odgers, R., \& Giroux, I. (2009). Internationalizing faculty: A phased approach to transforming curriculum design and instruction. In R. D. Trilokekar, G. A. Jones, \& A. Shubert (Eds.), Canada's universities go global (pp. 252-276). Toronto, ON: James Lorimer and Company.

Pluim, G., \& Jorgenson, S. (2012). A reflection on the broader, systemic impacts of youth volunteer abroad programs: A Canadian perspective. Intercultural Education, 23(2), 25-38.

Said, E. (1978). Orientalism. New York, NY: Penguin.

Sandmann, L. R., Moore, T. L., and Quinn, J. (2012). Center and periphery in servicelearning and community engagement: A postcolonial approach. In J. A. Hatcher \& R. G. Bringle (Eds.), Understanding service learning and community engagement: Crossing boundaries through research (pp. 25-46). Charlotte, NC: Information Age Publishing.

Schroeder, K., Wood, C., Galiardi, S., \& Koehn, J. (2009). First, do no harm: Ideas for mitigating negative community impacts of short-term study abroad. Journal of Geography, 108(3), 141-147.

Sharpe, E. K., \& Dear, S. (2013). Points of discomfort: Reflections on power and partnerships in international service-learning. Michigan Journal of Community Service Learning, 2O(1), 49-57.

Shultz, L., Abdi, A., \& Richardson, G. (2011). Global citizenship education in postsecondary institutions. New York, NY: Peter Lang. 
Spivak, G. (1985). The Rani of Sirmur. In F. Barker, P. Hulme, M. Iverson, \& D. Loxley (Eds.), Europe and its others (pp. 128-151). Colchester, UK: University of Essex.

Spivak, G. (1988). Can the subaltern speak? In C. Nelson \& L. Grossberg (Eds.) Marxism and the interpretation of culture (pp. 271-316). Chicago, IL: University of Illinois Press.

Spivak, G. C. (1990). Criticism, feminism, and the institution. In S. Harasym (Ed.), The post-colonial critic: Interviews, strategies, dialogues (pp. 1-16). New York: NY: Routledge, Chapman and Hall. (Original work published 1984/85)

Stake, R. A. (1988). Case study methods in educational research. In R. M. Jaeger (Ed.), Complementary methods for research in education (pp. 253-300). Washington, DC: American Educational Research Association.

Stake, R. A. (1994). Case studies. In N. K. Denzin \& Y. S. Lincoln (Eds.), Handbook of qualitative research (pp. 236-247). London, UK: Sage.

Taraban, S., Trilokekar, R. D., \& Fynbo, T. (2009). Promoting global learning through international internships. In R. D. Trilokekar, G. A. Jones, \& A. Shubert (Eds.), Canada's universities go global (pp. 213-237). Toronto, ON: James Lorimer and Company.

Trilokekar, R. D. (2010). International education as soft power? The contributions and challenges of Canadian foreign policy to the internationalization of higher education. Higher Education, 59, 131-147.

Yin, R. K. (2014). Case study research: Design and methods (5th ed.). Thousand Oaks, CA: Sage.

\section{Contact Information}

Marianne A. Larsen

Faculty of Education

University of Western Ontario

mlarsen@uwo.ca

Marianne A. Larsen is an associate professor at the Faculty of Education, University of Western Ontario. Her current areas of research are the internationalization of higher education and, in particular, international service learning (ISL). Her research on the impact and influence of ISL on global South host communities appears in her 2015 edited book International Service Learning: Engaging Host Communities. She is also working on a single-authored book bringing together her interest in internationalization processes with new spatial theorizing that focuses on patterns of flows and interconnections between people, institutions, and ideas. 